\title{
Legal Outlook of Fiscal Operation in Nepal
}

\section{Suman Acharya, PhD}

\author{
Email: sumanacharaya@gmail.com
}

Submission Date: September 2, 2020.

\begin{abstract}
No legal person can be operated without legal mandate. As State and their body are the part of legal person, they can perform their task only based on legal provision. As the fiscal operation is important function of state machinery, state enacts laws for revenue, expenditures, domestic and foreign aid, foreign investment etc. Even the political and legal picture of the country determines budgetary policy and its operation. Fiscal operation of the country has been done through the operationalization of legal mandates under principal and delegated legislation. Prevailing Constitution of Nepal is the stepping stone for fiscal policy for Nepal which has followed socialism oriented liberal market economy policy. Based on the constitutional provisions, various revenue, expenditure, and auditing related laws have been enacted. Together with the budget, Appropriation Act, Supplementary Estimates Act, Votes of Account Act, Votes of Credit Act, Contingency Fund Act are enacted as per necessity and other revenue related laws are also amended to make them compatible with newly issued budget statements each years.
\end{abstract}

Keywords: budget, revenue, assistance, debt, capital flow, avoidance of double taxation, prevention of fiscal evasion

\section{Introduction}

In ancient time, there was limited task of the government and had belief that the government had to maintain peace and security only and other functions were to be performed by people. However, in modern days, the scope of the government has been expanded not limiting only in war but to the social welfare. So, the revenue and expenditures of the governments are important dimensions of public finance management. Fiscal policy guides public finance management related issues. Classical theory of economics argues that government shouldn't make wide range of expenditures and should allow private sector to perform their task. However, modern theory 
supports for much more expenditure to be made by the government and regulation of the economy by the government. Classical thought rejected the interference of the government in economic activities whereas modern school of thought allows regulation in economic activities from the government. Recently Nepal follows three pillars of the economy which are public, private and cooperative sectors. National policies are formulated in same basis. Widely used macro policy for economic stability and growth are fiscal and monetary policy.

- Fiscal Policy: It is the policy of the government to maintain saving, investment, consumption, pricing and national income etc. Economic growth and expansions are the motto of the fiscal policy. There are automatic stabilization fiscal policy, compensatory fiscal policy and discretionary fiscal policy. ${ }^{1}$ In automatic stabilization policy, built-inflexibility in tax revenue and expenditure has been arranged with the ratio of increasing and decreasing of GDP. Compensatory fiscal policy desires for compensation in deficiency to reduce aggregate demand. Deficit budgeting is proposed in depression time whereas surplus budgeting is proposed in high rate of inflation. In discretionary fiscal policy, taxation and expenditures are changed automatically as per requirement. Moreover, anti inflationary and counter cyclical fiscal policy are also important policies. In anti inflationary policy, there will be a try to keep inflation in minimum level and in countercyclical fiscal policy, there are the method of changing tax by keeping government spending constant or changing government spending by keeping tax constant or equal change in tax and spending and changing tax in smaller than government spending to control cyclical effects. ${ }^{2}$ There are two types of strategy of fiscal policy which are crowding out effect of deficit spending which makes adverse effect to private sectors and crowding in effect of surplus spending which makes rise in the private investment.

- Monetary Policy: Price stability, foreign exchange stability, adjustment of demand and supply of money, credit control, creation and expansion of financial institutions, suitable interest rate and debt management are the basic functions of monetary policy. It is made

\footnotetext{
DN Dwivedi. Macroeconomics Theory and Policy, 3rd edition. 604 (2010). McGraw Hill Education (India) Private Limited: New Delhi.

Vide Tulashi Prasad Ghimire et.al. Public Finance. 140 (2012). Dreamland Publication.
} 
based on fiscal policy provision by the central bank of the country. It has contractionary and expansionary monetary policy as per the need of the market liquidity.

\section{Fiscal Laws in Nepal}

- Constitution of Nepal, 2072 BS (2015 AD) for fiscal policy and Auditor General

- Value Added Tax Act, 2052 BS (1995 AD) and Its Rules, 2054 BS (1996 AD)

- Income Tax Act, 2058 BS (2002 AD)

- Excise Duty Act, 2058 BS (2002 AD) and Its Rules, 2059 BS (2002 AD)

- Custom Duty Act, 2064 BS (2007 AD) and Its Rules, 2064 BS (2007 AD)

- Wealth Tax Act, 2047 BS (1990 AD)

- Revenue Tribunal Act, 2031 BS (1974 AD)

- Revenue Leakage (Investigation and Control) Act, 2052 BS (1995 AD) and its Rules, 2070 BS (2014 AD)

- Periodic Tax Recovery Act, 2012 BS (1955 AD)

- Land Revenue Act, 2034 BS (1978 AD)

- Stamp Duty Act, 2019 BS (1963 AD)

- Transport Management Act, 2049 BS (1993 AD) and Vehicle and Transport Management Rules, 2054 BS (1997 AD)

- Liquor Act, 2031 BS (1974 AD)

- Financial Procedure and Financial Accountability Act, 2076 BS (2020 AD)

- Public Debt Act, 2058 BS (2002 AD)

- Loan and Guarantee Act, 2025 BS (1968 AD)

- Audit Act, 2075 BS (2019 AD)

- Economic Act (Each year)

\section{Fiscal Instruments}

\begin{tabular}{|l|l|l|}
\hline S.N. & Issues & Explanation \\
\hline $\mathbf{1}$ & Budgetary & $\begin{array}{l}\text { Broadly there are two types budget namely balanced budget and } \\
\text { unbalanced budget. Unbalanced budget include surplus budget and } \\
\text { Policy }\end{array}$ \\
$\begin{array}{l}\text { peficit budget. Under the Constitution of Nepal, Budget must be } \\
\text { promulgated within mid of May so that implementing agencies get }\end{array}$ \\
\hline
\end{tabular}




\begin{tabular}{|c|c|c|}
\hline & & $\begin{array}{l}\text { sufficient time for implementation of program. Fiscal year ranges from } \\
16 \text { July to } 15 \text { July. Prior than formulation of budget, revenue and } \\
\text { expenditure information are forecasted by the involvement of the } \\
\text { National Planning Commission, Ministry of Finance, Central Bank of } \\
\text { Nepal and Financial Controllers General's Office. Then, Budget } \\
\text { Committee is formed with the involvement of Ministry of Finance and } \\
\text { National Planning Commission. All institutions prepare budget and } \\
\text { program and dispatches to Ministry of Finance and National Planning } \\
\text { Commission through concerned line ministry. Budgetary Committee } \\
\text { allocates budget as per necessity and relevancy. Budget has been } \\
\text { allocated in Nepal with the title of recurrent, capital and financial } \\
\text { expenditures. }\end{array}$ \\
\hline 2. & Expenditure & $\begin{array}{l}\text { Expenditure policy is mentioned in budget through annual program of } \\
\text { various ministry, departments and public organizations. Principle of } \\
\text { benefit, economy, public approval, saving, productivity, flexibility and } \\
\text { equality are applicable to maintain expenditures of the government. } \\
\text { Adam Smith proposed defence, development and commercial } \\
\text { expenditures of the government whereas Cohn and Plehn proposes } \\
\text { general benefit, benefit to special circle, benefit to person and society } \\
\text { both, and benefit to specific person. Yet, Nicholson recommends making } \\
\text { expenditures on the area having no return to the government, area of long } \\
\text { term and indirect return, area of partial income and are of sufficient } \\
\text { income. Moreover, Hicks support for defensive, administrative, } \\
\text { economic and social expenditures of the government. J.S. Mill covers } \\
\text { necessary expenditures and voluntary expenditures and Pigou purposes } \\
\text { for transferable and non transferable government expenditures. } \\
\text { Nevertheless, Nepal follows the modality of general expenditures and } \\
\text { development expenditures. Nepalese government expenditures are } \\
\text { classified as recurrent, capital and financial expenditures. In previous } \\
\text { days, allocated budget was not fully expensed because of the political } \\
\text { transition. It is expected that all the allocated budget is expensed and }\end{array}$ \\
\hline
\end{tabular}




\begin{tabular}{|c|c|c|}
\hline & & $\begin{array}{l}\text { economic growth will be maintained. Budget in Nepal has been expensed } \\
\text { as recurrent, capital and financial portion of the budget. Financial } \\
\text { Procedure and Financial Accountability Act, } 2076 \text { BS (2020 AD) } \\
\text { controls the expenditure process. }\end{array}$ \\
\hline 3. & Revenue & $\begin{array}{l}\text { There are tax revenue and non tax revenue. Tax revenue is received from } \\
\text { Value Added Tax, Custom Duty, Excise Duty, Income tax, Educational } \\
\text { Service Tax, Health Service Tax, other tax and Vehicle Tax. Adam } \\
\text { Smith purposes equity, certainty, convenience and economy principles } \\
\text { for taxation whereas Bestable purposes productivity, elasticity, diversity, } \\
\text { simplicity, expediency, surplus and coordination principle for taxation } \\
\text { system. }{ }^{4} \text { Revenue related cases are filed in Director General and Revenue } \\
\text { Tribunal. Under the consent of Supreme Court, it can be appealed to }_{\text {Supreme Court. }{ }^{5} \text { It also accepts tax related writ as well. }}\end{array}$ \\
\hline 4. & Public Debt & For internal debt, Nepal Rastra Bank is responsible under the fiscal \\
\hline
\end{tabular}

3 Financial Procedure and Financial Accountability Act, 2076 BS (2020 AD). http://www.moljpa.gov.np/wpcontent/uploads/2019/10/\%E0\%A4\%86\%E0\%A4\%B0\%E0\%A5\%8D\%E0\%A4\%A5\%E0\%A4\%BF\%E0\%A4\%95\%Е0\%A4\%95\%Е0\%A4\%BE\%E0\%A4\%B0\%Е0\%A5\%8D\%E0\%A4\%AF\%E0\%A4\%B5\%Е0\%A4\%BF\%Е0\%A4\%A 7\%E0\%A4\%BF-\%E0\%A4\%A4\%E0\%A4\%A5\%E0\%A4\%BE\%Е0\%A4\%B5\%Е0\%A4\%BF\%E0\%A4\%A4\%E0\%A5\%8D\%E0\%A4\%A4\%E0\%A5\%80\%E0\%A4\%AF\%Е0\%A4\%89\%Е0\%A4\%A4\%E0\%A5\%8D\%E0\%A4\%A4\%E0\%A4\%B0\%E0\%A4\%A6\%E0\%A4\%BE\%E0\%A4\%A F\%E0\%A4\%BF\%E0\%A4\%A4\%E0\%A5\%8D\%E0\%A4\%B5-\%E0\%A4\%90\%Е0\%A4\%A8\%E0\%A5\%A8\%E0\%A5\%A6\%E0\%A5\%AD\%E0\%A5\%AC.pdf. (Last Visited on 9/1/2020).

4 Tax is regarded as compulsory contribution from the tax payer, which will be spent for public purpose. It is for raising revenue of the state. It is taken as quid pro quo (a favor or advantage granted in return for something). To pay tax is legal duty. Some of the theory of tax are :

- Welfare Theory: The function of state is extended from protection to rights to social welfare, the rate and types of taxation are extended.

- Imperative theory: Imposition of tax is legal mandate. No taxation without representation is universally accepted principles. Taxation law should be certainty, transparent, self-explanatory and easy. Tax law should not be retrospective operation. Law of taxation is known as a complete court as it covers the substantial, procedural and institutional provision together.

- Service-Value Theory: Government provides goods and services to the people for their welfare and in return people have to pay tax. The contribution is incalculable.

- Gain Theory: The tax should be paid as per the proportion of gain which increases the level of paying capacity.

Vide Tax Related Precedent. https://ird.gov.np/public/pdf/210528749.pdf. (Last Visited on 9/1/2020). 


\begin{tabular}{|c|c|c|}
\hline & & $\begin{array}{l}\text { policy, which established Public Debt Management Department. It uses } \\
\text { repo, reverse repo, outright sale, outright purchase, deposit collection, } \\
\text { standing liquidity facilities and NRB Bond to collect loans. Treasury } \\
\text { Bills, National Saving Bond, Development Bond, Citizen Saving Bond, } \\
\text { Foreign Employment Saving Bond, prize bond, bearer bond, special bond } \\
\text { and other bonds as per directed are used as an instruments for the purpose } \\
\text { of public debt management. }{ }^{6} \text { Internal sources of public debt are person, } \\
\text { financial institutions, commercial bank and central bank whereas external } \\
\text { sources are debt from foreign country and intergovernmental and non } \\
\text { governmental agencies. Public debt can be classified as internal and } \\
\text { external debt, productive and unproductive debt, voluntary and } \\
\text { compulsory debt, funded and non funded debt, interest bearing and } \\
\text { interest free debt, gross and net debt, marketable and non marketable debt } \\
\text { etc. The Loan and Guarantee Act, } 2025 \text { BS (1968 AD) is applicable law } \\
\text { for foreign debt which is amended annually with the requirement of the } \\
\text { budget. It has delimited up to } 14 \text { billion USD for FY 2020/2021. }{ }^{7} \text { For } \\
\text { domestic debt, Nepal Rastra Bank works as a manager of domestic debt } \\
\text { based on budgetary policy. }\end{array}$ \\
\hline 5. & $\begin{array}{l}\text { External } \\
\text { Assistance }\end{array}$ & $\begin{array}{l}\text { External assistance is also used to balance external sector. It covers very } \\
\text { small portion of the economy. In fact, it has not been encouraged by the } \\
\text { country as it is not substantial source for the economy because of its } \\
\text { inflexible nature. It has the filler contribution. Nepal has issued } \\
\text { International Development Cooperation Policy, } 2075 \text { BS (2019 AD). }{ }^{8}\end{array}$ \\
\hline 6. & Capital Flow & $\begin{array}{l}\text { Nepal does not allow direct capital movement from one country to } \\
\text { another. There are certain procedures of foreign investment though which }\end{array}$ \\
\hline
\end{tabular}

Vide Nepal Rastra Bank Debt Management Guideline, 2074.

The Loan and Guarantee Act, 2025 BS (1968 AD). http://www.moljpa.gov.np/wpcontent/uploads/2020/07/\%E0\%A4\%8B\%E0\%A4\%A3-\%E0\%A4\%A4\%E0\%A4\%A5\%E0\%A4\%BE$\% \mathrm{E} 0 \% \mathrm{~A} 4 \% 9 \mathrm{C} \% \mathrm{E} 0 \% \mathrm{~A} 4 \% \mathrm{AE} \% \mathrm{E} 0 \% \mathrm{~A} 4 \% \mathrm{BE} \% \mathrm{E} 0 \% \mathrm{~A} 4 \% \mathrm{~A} 8 \% \mathrm{E} 0 \% \mathrm{~A} 4 \% \mathrm{~A} 4-$ $\% \mathrm{E} 0 \% \mathrm{~A} 4 \% 9 \mathrm{~A} \% \mathrm{E} 0 \% \mathrm{~A} 5 \% 8 \mathrm{C} \% \mathrm{E} 0 \% \mathrm{~A} 4 \% \mathrm{AC} \% \mathrm{E} 0 \% \mathrm{~A} 5 \% 80 \% \mathrm{E} 0 \% \mathrm{~A} 4 \% \mathrm{~B} 8 \% \mathrm{E} 0 \% \mathrm{~A} 5 \% 8 \mathrm{C} \% \mathrm{E} 0 \% \mathrm{~A} 4 \% 82-$ $\% \mathrm{E} 0 \% \mathrm{~A} 4 \% \mathrm{~B} 8 \% \mathrm{E} 0 \% \mathrm{~A} 4 \% 82 \% \mathrm{E} 0 \% \mathrm{~A} 4 \% \mathrm{~B} 6 \% \mathrm{E} 0 \% \mathrm{~A} 5 \% 8 \mathrm{~B} \% \mathrm{E} 0 \% \mathrm{~A} 4 \% \mathrm{~A} 7 \% \mathrm{E} 0 \% \mathrm{~A} 4 \% \mathrm{~A} 8-$ \%E0\%A4\%90\%E0\%A4\%A8-\%E0\%A5\%A8\%E0\%A5\%A6\%E0\%A5\%AD\%E0\%A5\%AD.pdf. This law has been updated annually in the time of Budget Issue.

8 International Development Cooperation Policy, 2075. https://mof.gov.np/uploads/document/file/print copy IDCMP2019_Eng-fullpage_20191107071739.pdf. (Last Visited on 9/1/2020). 


\begin{tabular}{|l|l|}
\hline & $\begin{array}{l}\text { capital can be brought in and dividend and repatriation of capital are } \\
\text { arranged under Foreign Investment and Technology Transfer Act, } 2075 \\
\text { BS (2019 AD) and Foreign Exchange (Management) Act, } 2019 \text { BS (1962 } \\
\text { AD). Other relevant prevailing laws are applicable to complete this } \\
\text { process. Generally GDP and foreign investment ratio follows } 2.3 \text { percent } \\
\text { in developing countries which is only 0.6 percent in Nepal GDP although } \\
\text { Nepal made conducive environment. }\end{array}$ \\
\hline
\end{tabular}

\section{Financial Procedures under Constitution of Nepal, 2072 BS (2015 AD)}

No taxation can be levied in the absence of law. ${ }^{9}$ Even loan can be raised or guarantee can be given by the government in the absence of federal law. ${ }^{10}$ All the revenues and receipt are collected in federal consolidated fund. ${ }^{11}$ It is expensed under Federal Appropriation Act, Supplementary Appropriation Act, Federal Votes of Account Act and Federal Vote of Credit Act etc. Annual budget presents estimated revenues, moneys required to meet the charges on the Federal Consolidated Fund, and moneys required to meet the expenditure to be provided for by a Federal Appropriation Act, which is presented by the Minister for Finance in mid May annually. ${ }^{12}$ If the particular mentioned in Appropriation Act is not sufficient, supplementary estimates can be presented by the Minister for Finance. ${ }^{13}$ When appropriation Bill is under consideration, one-third of the estimate of expenditures for the financial year is received from Votes on Account. ${ }^{14}$ In an emergency situation due to either natural causes or a threat of external aggression or internal disturbances or other reasons, Minster for Finance may purpose for Vote of Credit Bill for required expenditures. ${ }^{15}$ Federal contingency fund is required to establish for unforeseen expenditures. ${ }^{16}$

Constitution of Nepal § Article 115(1) (2072 BS).

Id. $\S$ Article 115(2).

Id. § Article, 116.

Id. § Article 119.

Id. § Article 121.

Id. § Article, 122.

Id. § Article 123.

Id. § Article 124. 
State also cannot levy taxation or raise loan or give guarantee without law. ${ }^{17}$ The State Minister for Finance presents estimation of budget in respect of every financial year. ${ }^{18}$ There are also the provisions on State Appropriation Bill, ${ }^{19}$ Supplementary Appropriation Bill, ${ }^{20}$ State Vote on Account Bill, ${ }^{21}$ Vote of Credit Bill. ${ }^{22}$ State Contingency Fund is also established for unforeseen expenses. ${ }^{23}$ The Local level may levy tax by law on matters falling within its domain without prejudice to national economic policies, carriage of goods and services, capital and labor market, and the neighboring State or Local level. ${ }^{24}$ Local Consolidate Fund is established by each village body and municipality. ${ }^{25}$ Estimates of revenues and expenditures of Village Body and Municipality must be passed by the Village Assembly and the Municipal Assembly respectively. ${ }^{26}$ The source of the deficit budget must be mentioned under prevailing law by local body as well.

\section{Taxation policy}

The Inland Revenue Department is currently responsible for the administration of Value Added Tax, Income Tax, and Excise Duty whereas Department of Custom is responsible to collect custom duty. And, Transportation Management Department is responsible to collect vehicle tax. Except educational and health social security tax, other health and educational taxations are removed by the government of Nepal. Taxation is classified as direct tax, indirect tax, proportional tax, progressive tax and regressive tax. Nepal follows progressive tax system to the large extent. Taxable capacity is also measured based on absolute taxable capacity and relative taxable capacity. Taxation requires imposing to the extent that people cannot stop production capability. In fact, it is determined by population growth, distribution of wealth, national income, political condition, psychology of people, price levels, economic development level etc.

Id. § Article 203.

Id. § Article 207.

Id. § Article 208.

Id. § Article 209..

Id. § Article 210.

Id. § Article 211.

Id. § Article, 212.

Id. § Article 228 (2).

Id. § Article 229.

Id. § Article 230. 


\section{Tax and Non Tax Revenue in Nepal}

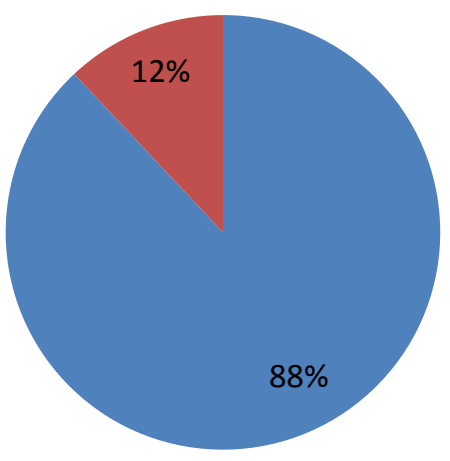

1 Tax

2 Non Tax

\section{- Tax revenue}

88 percent share of total revenue is from tax revenue and remaining percentage is covered from non tax revenue in Nepal. Generally, there was the 29 percent contribution of value added tax, 28 percent of income tax, 19 percent of custom duty, and 16 percent of excise duty, which slightly deviates year in year out.

\section{Distribution of Tax in Nepal}

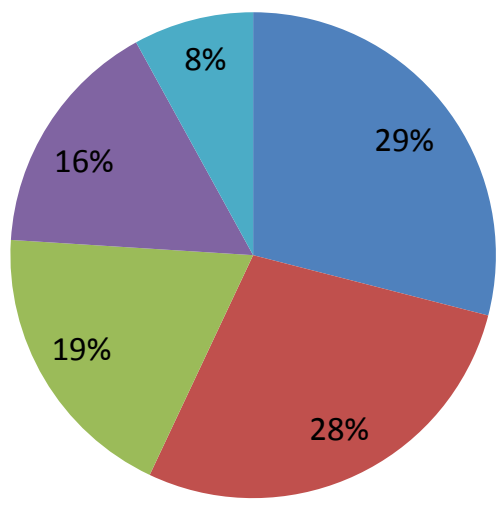

1 VAT

2 Income Tax

3 Custom

4 Excise Duty

5 Others

In the paying tax index of 2017, Nepal received 66.50 point and in 142 out of 189 countries of the world. In a same year, tax revenue has 18.74 percent and non tax revenue 
has 2.73 percent in total Gross Domestic Product of Nepal. ${ }^{27}$ In 2019, Nepal is graded 135th in starting a business indicator; 97th in registering property; and 175th in paying taxes Index. ${ }^{28}$ It is the ranking of the World Bank.

\section{Types of taxation}

- Progressive taxation: Tax burden is arranged based on the income level of individuals. Higher the income, higher the tax and lower the income lower the tax has been arranged.

- Regressive taxation: The rate of tax will be decreased once the income has been increased.

- Proportional taxation: In this tax system, equal percentage of taxation is imposed for all without any discrimination.

- Digressive tax: The rate of taxation will be increased up to certain level and gradually decreases with the increase of the income.

- Direct vs. Indirect Tax: The impact and incidence of the tax cannot be shifted in direct tax whereas it can be shifted to other party gradually.

\section{Taxation System in Nepal}

\begin{tabular}{|l|l|l|}
\hline S.N. & Issues & Explanations \\
\hline 1. & VAT & $\begin{array}{l}\text { Value added tax is an indirect tax, which is imposed on goods and } \\
\text { services at each stage of production, starting from raw materials } \\
\text { to final product. VAT is levied on the value additions at different } \\
\text { stages of production. VAT rate is 13\% on the goods and service } \\
\text { subject to VAT in Nepal. VAT Act, 2052 BS (1995 AD) and its } \\
\text { Rules 2054 BS (1996 AD) are applicable laws. }\end{array}$ \\
\hline 2. & Custom Duty & $\begin{array}{l}\text { It taxes on import and export center of products. There are custom } \\
\text { offices in different border area and in international airport which } \\
\text { collect custom duty. It is controlled by the Department of the } \\
\text { Custom. Custom Act, 2064 BS (2007 AD) and it rules } 2064 \text { BS }\end{array}$ \\
\hline
\end{tabular}

$27 \quad$ Vide Report of Revenue Advisory Committee, 2074.

http://mof.gov.np/uploads/document/file/Full\%20Revenue\%20Advisory\%20Committee\%20Report 20170608112142. pdf. (Last visited on 12/6/2018).

28 https://thehimalayantimes.com/business/nepal-ranks-94th-in-doing-businessindex/\#: :text=Nepal\%20is\%20ranked\%20135th\%20in,taxes\%20by\%20the\%20World\%20Bank. 


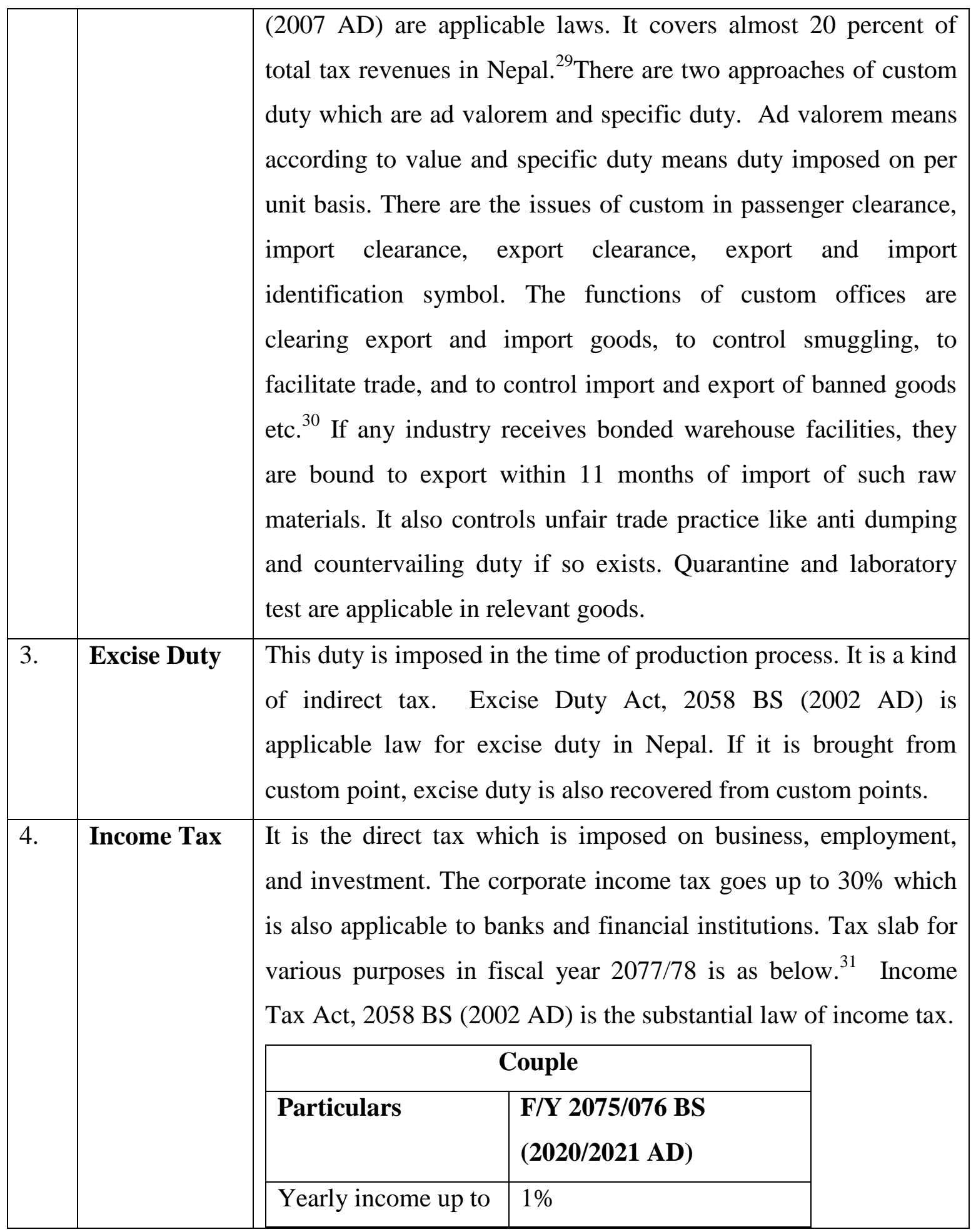

Department of Custom. A Secure Business Environment for Economic Development. https://www.customs.gov.np/en/. (Last Visited on 12/5/2018).

30 Vide Frequently Asked Questions. https://www.customs.gov.np/en/faq.html. (Last Visited on 12/6/2018).

31 Tax Rate in Nepal for FY 2077/78. https://www.investopaper.com/news/tax-rate-in-nepal/. (Last Visited on 8/31/2020. 


\begin{tabular}{|c|c|c|c|c|}
\hline & & $4,50,000$ & & \\
\hline & & Additional 1,00,000 & $10 \%$ & \\
\hline & & Additional 2,00,000 & $20 \%$ & \\
\hline & & Additional & $30 \%$ & \\
\hline & & $12,50,000$ & & \\
\hline & & Additional tax above & $36 \%$ & \\
\hline & & $20,00,000$ and above & & \\
\hline & & & dividual & \\
\hline & & Particulars & $\begin{array}{l}\text { F/Y 2075/076 BS } \\
(2020 / 2021 \text { AD) }\end{array}$ & \\
\hline & & $\begin{array}{l}\text { Yearly income up to } \\
4,00,000\end{array}$ & $1 \%$ & \\
\hline & & Additional 100000 & $10 \%$ & \\
\hline & & Additional 200000 & $20 \%$ & \\
\hline & & Additional 1300000 & $30 \%$ & \\
\hline & & $\begin{array}{l}\text { Additional tax above } \\
20,00,000 \text { and above }\end{array}$ & $36 \%$ & \\
\hline 5. & $\begin{array}{l}\text { Educational } \\
\text { and Health } \\
\text { Service Tax }\end{array}$ & $\begin{array}{l}\text { One percent taxation i } \\
\text { security taxation. Othe } \\
\text { ongoing Budget perfo } \\
\text { service fee and healths }\end{array}$ & $\begin{array}{l}\text { levied in educational and } \\
\text { educational and health tar } \\
\text { rming welfare state conce } \\
\text { ervice fee waived for the ti }\end{array}$ & $\begin{array}{l}\text { health as social } \\
\text { is removed by } \\
\text { pt. Education } \\
\text { ne being. }\end{array}$ \\
\hline 6. & Vehicle Tax & $\begin{array}{l}\text { This tax is collected by } \\
\text { recovered annually. Ta } \\
\text { Tax has increased on } \\
150 \text { CC. Transport M } \\
\text { Vehicle and Transport } \\
\text { are applicable laws. }\end{array}$ & $\begin{array}{l}\text { Transport Management D } \\
\mathrm{x} \text { is increased on vehicles a } \\
\text { ars above } 1000 \mathrm{CC} \text { and } \mathrm{m} \\
\text { anagement Act, } 2049 \mathrm{BS} \\
\text { Management Rules, } 2054\end{array}$ & $\begin{array}{l}\text { partment. It is } \\
\text { dd motorcycles. } \\
\text { torcycle above } \\
1993 \text { AD) and } \\
\text { BS (1997 AD) }\end{array}$ \\
\hline 7. & Wealth Tax & $\begin{array}{l}\text { A wealth tax is levied } \\
\text { flow, which is impose }\end{array}$ & $\begin{array}{l}\text { on purchasing power of } s \\
\text { d under Wealth Tax Act, }\end{array}$ & $\begin{array}{l}\text { ock rather than } \\
2047 \text { BS (1990 }\end{array}$ \\
\hline
\end{tabular}




\begin{tabular}{|c|c|c|}
\hline & & AD). The responsibility to raise this tax goes to local bodies. \\
\hline 8. & $\begin{array}{l}\text { Land } \\
\text { Revenue }\end{array}$ & $\begin{array}{l}\text { Land Revenue is required to be paid by a land owner to } \\
\text { Government of Nepal under Land Revenue Act, } 2034 \text { BS (1978 } \\
\text { AD). It also includes any fee (penalty) payable for non-payment } \\
\text { of the land revenue within the time-limit referred to in this Act. }\end{array}$ \\
\hline 9. & Stamp Duty & $\begin{array}{l}\text { This duty is levied only on deed of loan or memorandum on } \\
\text { household transaction of more than One Thousand Rupees. Postal } \\
\text { stamp may be affixed instead of the Stamp to the document } \\
\text { subject to the Stamp duty until the Stamp is available. According } \\
\text { to the preamble of the Stamp Duty Act, } 2019 \text { BS (1963 AD), it is } \\
\text { made to levy stamp duty on the documents of income related } \\
\text { transactions and manage the modus operandi pertaining to } \\
\text { such stamp duty. Rate of the Stamp duty is determined as per } \\
\text { face value rate as below. } \\
\text { - Up to Rs. } 100 /- \text { None } \\
\text { - From Rs. } 101 /- \text { to } 250 /- \text { Re. } 1 /- \\
\text { - From Rs. } 251 / \text { to } 500 /- \text { Rs. } 2 /- \\
\text { - From Rs. } 501 /- \text { to } 750 /- \text { Rs. } 3 /- \\
\text { - Per Rs. } 751 /- \text { to } 1000 /- \text { Rs. } 4 /-\end{array}$ \\
\hline 10. & $\begin{array}{ll}\text { Non } & \text { Tax } \\
\text { Revenue } & \end{array}$ & $\begin{array}{l}\text { Interest, dividend, rent and royalties, amount received from sales } \\
\text { of goods, administrative service fee, penalty, fine and } \\
\text { confiscation, voluntary transfer other than subsidy, tourism and } \\
\text { visit administrative fee, other revenues and capital revenues are } \\
\text { the title for non tax revenue in Nepal. }\end{array}$ \\
\hline
\end{tabular}

\section{Avoidance of Double Taxation Agreement}

International taxation has two dimensions which are territorial approach and another is extraterritorial approach. All resident having transaction within a country is subject to taxation 
under territorial approach and all income from abroad made by national can be the subject of taxation if so is received in a country under extra territorial approach. However, bilateral and multilateral agreement may check in the imposition of international taxation. Nepal has entered into taxation agreement to remove double taxation in income tax with People Republic of China, India, Mauritius, Sri Lanka, Pakistan, Republic of Korea, Thailand, Austria, Norway and Qatar which are as under. ${ }^{32}$

- Agreement between the Government of Nepal and the Kingdom of Norway for the Avoidance of Double Taxation and the Prevention of Fiscal Evasion with respect to Taxes on Income and on Capital, 1996

- Agreement between the Government of Nepal and the Government of the kingdom of Thailand for the Avoidance of Double Taxation and the Prevention of Fiscal Evasion with respect to Taxes on Income, 1998

- Agreement between the Government of Nepal and the Democratic Socialist Republic of Sri Lanka for the Avoidance of Double Taxation and the Prevention of Fiscal Evasion with respect to Taxes on Income, 1999

- Agreement between the Government of Nepal and the Government of the Republic of Mauritius for the Avoidance of Double Taxation and the Prevention of Fiscal Evasion with respect to Taxes on Income, 1999

- Agreement between the Government of Nepal and the Republic of Austria for the Avoidance of Double Taxation and the Prevention of Fiscal Evasion with respect to Taxes on Income, 2000

- Agreement between the Government of Nepal and the Government of the Islamic Republic of Pakistan for the Avoidance of Double Taxation and the Prevention of Fiscal Evasion with respect to Taxes on Income, 2001

- Agreement between the Government of Nepal and the Government of the Peoples Republic of China for the Avoidance of Double Taxation and the Prevention of Fiscal Evasion with respect to Taxes on Income, 2001 
- Agreement between the Government of Nepal and the Republic of Korea for the Avoidance of Double Taxation and the Prevention of Fiscal Evasion with respect to Taxes on Income, 2001

- Agreement between the Government of Nepal and the Government of the State of Qatar for the Avoidance of Double Taxation and the Prevention of Fiscal Evasion with respect to Taxes on Income, 2007

- Agreement between the Government of Nepal and the Government of the Republic of India for the Avoidance of Double Taxation and the Prevention of Fiscal Evasion with respect to Taxes on Income, 2011

- SAARC Limited Multilateral Agreement on Avoidance of Double Taxation and Mutual Administrative Assistance in Tax Matters, 2005

\section{Role of Fiscal Policy Operation}

Fiscal policy is the backbone to run and stabilize economy of the country based on internal and external factors of economy. It is all about income and expenditures of the government. The role of fiscal policy can be depicted as below.

- Economic Growth and Development: By expanding the rate of investment in private sectors, government initiates acceleration of economic growth in a country. ${ }^{33}$

- Creation and Encouragement for Employment: There can be cyclical, structural, technological, frictional and seasonal unemployment. ${ }^{34}$

- Reduction of Inequality and Measure of Upliftment: with different upliftment program and redistribution of income, equality can be maintained in the society and the nations. $^{35}$

- Balance of External Trade and Balance of Payment: It tries to maintain stability in balance of trade and balance of payment of the country so that economy can be run normally. 36

\footnotetext{
33 DN Dwivedi. Macroeconomics Theory and Policy, 3rd edition. 610 (2010). McGraw Hill Education (India) Private Limited: New Delhi.

Id. $\S 612$.

Id, $\S 614$.

Id.
} 
- Balanced Distribution of National Income: National income requires distributing equally with the equity among people. Low income earner and marginalized people must be strengthened with the support of distribution and redistribution of income.

- Generation of capital for Investment: Social and economically required infrastructures are created by the government and private sectors jointly. Government and monetary authority present different scheme for forced saving which can be utilized for the national development and infrastructure formation in a country.

- Mitigation of Inflationary Pressure: Normal rate of inflation is necessary to create employment and gear economy but high level of inflation creates problem in a society. So, monetary and fiscal authority tries to curve the inflation.

- Overall Economic Sector Stability: By the expansionary or contractionary fiscal and monetary policy, economic stability in the country is maintained.

- Proportionate Development of Various Localities: Country has different localities, geography and circumstances. Based on the initiation of economic activities, least developed or underdeveloped area can be developed.

- Reallocation and Mobilization of Resources: Resources may be captured my richer sect of the country. So, it is necessary to relocate natural and economic resources so that poor people can also get access to it. As there is very low rate of saving and investment in developing countries, government requires initiating natural resource mobilization etc requiring huge sum of the amount.

- Encouragement for Production and Consumption: Price support, procurement of particular goods and services and market management and subsidy help in the process of production and consumption which produces multiplier, acceleration and super multiplier effects.

- Utilization of Private Sector Capacity: Private sector has huge amount of money. If we can mainstream them, they can be the supporter of economic growth and the development.

\section{Challenges for Fiscal Policy Operation}

- Existence of Non Monetary Sectors: Commodity exchange system may not be covered by mainstream economic system. 
- Illiteracy and Lack of Mutual Support: Lack of good education and understanding of the economic and other activities hinder the development of the economy. People are not involved in income generating activities because of the illiteracy. People, company and society do not make cooperation in economic activities because of the selfishness. It hinders national development.

- Complexity for Quantification of Data and Manual Transaction: Quantitative data are not maintained in many developing countries. With the lack of proper record, it cannot be the part of state economic system. Modern technologies i.e. computer assisted software are not used because of the illiteracy and unavailability of it. These instruments are expensive which are not used by people in their economic transaction.

- Lack of Flexibility: Many economic activities are ousted from taxation because of the awkward system.

- Existence of Shadow Economy and Unrecorded Transaction: Hundi/Hawala, black marketing and informal transactions are not recorded which hinder in national fiscal policy to be implemented effectively. Because of manual transaction, no data and statistics are recorded effectively. In the absence of such data and figure, there is the availability of qualitative data only.

\section{Conclusion}

Fiscal policy operation is one of the important tools to make national growth and development. It tries to develop all nook and corner of the country by applying different fiscal instruments. Monetary and fiscal policies are important instruments to accelerate economy and maintain growth and development. Budget, expenditures, revenue, public debt and external assistances are the tools of fiscal policy. Monetary policy tries to be compatible with fiscal policy so that minimum level of growth can be maintained in a country. Yet, principal source of government income is tax revenue and non tax revenue. Debt and assistances are secondary sources of government receipt which are used to recover deficit financing of the country. International taxation law and double taxation avoidance treaty are also important part of fiscal management of the country. Constitution has provided rights and responsibilities to operate fiscal procedure for federal level, state level and local level government. Local level government may raise fund from local surcharges without harming federal transaction of goods and services. All machineries 
of the government are operated to utilize natural resources and fiscal resources so that quality of living and economic growth can be maintained. Fiscal policy and its operations are ultimately controlled and regulated by the amiable laws of the country.

'The End...' 